\title{
VIRTUAL CLASSROOM FOR ENGLISH LANGUAGE TEACHING
}

\author{
CJalalova I., ORCID: 0000-0003-4920-0786, Tashkent State University of Economics, Tashkent, \\ Uzbekistan,Ingrid74@inbox.ru \\ CSagdullakhojaev S., ORCID: 0000-0001-6858-2260, Tashkent State University of Economics, \\ Tashkent, Uzbekistan
}

\section{ВИРТУАЛЬНЫЙ КЛАСС ДЛЯ ОБУЧЕНИЯ АНГЛИЙСКОМУ ЯЗЫКУ}

\author{
СЖалалова И. М., ORCID: 0000-0003-4920-0786, Ташкентский государственный \\ экономический университет, Ташкент, Узбекистан, Ingrid74@inbox.ru \\ ССагдуллаходжаев С. А., ORCID: 0000-0001-6858-2260, Ташкентский государственный \\ экономический университет, Ташкент, Узбекистан
}

Abstract. Compared to previous generations, the educational process that students and teachers are currently going through is quite different. Primarily, the main cause of changes in education is due to the fast development of modern technology. Because of technology, students are eligible to learn beyond the classroom. Nowadays, teachers and students are able to use the internet to contact each other off university grounds. Instead of sitting face-to-face in a classroom, teachers can now educate their students anywhere, anytime. Today, teachers are beginning to take advantage of technology for educational purposes.

Аннотащия. По сравнению с предыдущими поколениями, образовательный процесс, через который проходят студенты и преподаватели, совершенно другой. Прежде всего, основная причина изменений в образовании связана с быстрым развитием современных технологий. Из-за технологии студенты имеют возможность учиться вне аудитории. В настоящее время преподаватели и студенты могут использовать интернет, чтобы общаться друг с другом за пределами вуза. Вместо того, чтобы сидеть лицом к лицу в аудитории, преподаватели теперь могут обучать своих студентов где угодно и когда угодно. Сегодня преподаватели начинают использовать технологии в образовательных целях.

Keywords: English teachers, modern technologies, virtual classroom, broadband Internet access, distance teaching.

Ключевые слова: преподаватели английского языка, современные технологии, виртуальный класс, широкополосный доступ в интернет, дистанционное обучение.

Perhaps you heard about virtual language classrooms and how the Internet has modernized distance teaching. Communication in a virtual classroom goes by means of electronic media like in an existent school. Students in a virtual classroom acquire language knowledge and skills by studying movies, texts, pictures, and by accomplishing various home assignments. Subsequent discussions help students to deepen their knowledge, develop their language and critical thinking skills. Discussion forums, chat rooms, voice mail and e-mail are often used for communication.

What is a Virtual Classroom? Unlike a physical classroom where the teacher and students are all in the same room, in a Virtual Classroom, the teacher and the students are all sitting in front of their computers somewhere. They are able to listen and speak to each other using their computers and microphones through the internet. This is what we call a virtual classroom. 
It is actually very similar to a physical classroom, in that:

-When one person speaks, the rest of the people in the room will be able to listen.

-A student needs to "raise hand" to request to speak, typically by clicking a button on the screen.

-There will be a whiteboard where the teacher can write down keywords, sentences.

With the ever-growing accessibility of the Internet, it is natural that the educational community is involved in making use of the tremendous resource of Virtual Classroom. Use of the Internet and Web are leading to significant changes in educational models. Effective exploitation of these changes requires adequate attention to understanding the technology, the educational process and issues, students' characteristics.

While this use of the Internet is increasing, a traditional classroom has been shifted to elearning and advancements in communication tools have been easily adapted to learning methods. Learning by a computer can be easy as communication with a professor and fellow classmates via email. Though, e-learning can be defined as an approach to facilitate and enhance learning by means of the Internet as students can read posted material online and download it for further access.

As far as students won't be in a classroom with a teacher and classmates, they will need to be capable of autonomous learning. The instructor will provide them with a syllabus, course documents, and required readings. The interaction between a teacher and students will be supported via e-mail, discussion board, forums etc. Since the class doesn't meet face-to-face at a scheduled time, students will have to learn independently. They will be responsible for keeping up with the assigned reading and completing assignments according to the timeline on the syllabus.

The growing popularity of e-learning has introduced new terms to education, as Virtual Classroom, where students will be present with their teacher and peers in a classroom. They will not be present physically in the classroom but connected to the classroom via the Internet. Virtual Classroom aims to stimulate the experience of attending a class over the web. So, everyone is able to see another participant virtually using a webcam and microphone with ear-phones.

Though as the term 'virtual' means a simulation of the real thing, Virtual Classroom is a simulated classroom via the Internet, which provides a convenient communication environment for distance learners just like a traditional face-to-face classroom. A Virtual Classroom allows learners to attend classes from anywhere in the world and aims to provide a learning experience that is similar to a real classroom.

When we go to a University, we have a schedule of lectures, which we must attend. Students must arrive on time, and when they enter the classroom, they find a teacher, peers, blackboard or whiteboard, overhead projector, optionally a television screen with videos. Likewise, a Virtual Classroom is a scheduled, online, teacher-led training session where teachers and learners interact together using computers linked to a network such as the Internet.

A Virtual Classroom enables to bring learners from around the world together online in highly interactive virtual classes while greatly reducing the travel, time, and expenses of on-site teaching programs. It can be used as a solution for live delivery and interaction that addresses the entire process of creating and managing our teaching-learning process. It facilitates instructor and students in teaching and learning events, such as seminars, online discussions or live training for colleagues.

As usual in a Virtual Classroom, there are a facilitator and learners and many participants present. They can talk with each other as in traditional classroom via chat, using voice and web camera. Similarly, presenter uses a whiteboard, gives notes / resources, and gives a presentation as in any traditional classroom. 
And now, when virtual classroom can be visualized as a classroom where a lecture or session is conducted using the Internet, there is an idea to discuss some advantages that virtual classroom offers over traditional classroom.

Virtual classroom allows learners and teachers to attend a single live training session from any place of the world, but they have to have a computer and perfect Internet connection. If learners miss a traditional classroom-based training session, they have very little opportunity to engage in the learning experience that took place. The good idea of Virtual Classroom is the given opportunity for those students who miss a lesson or training session by this or that reason to review the performance of any class activities or lecture as it has a facility to record a session and can be replayed afterwards.

It is worth of Virtual Classroom activities to be organized more quickly than traditional classroom-based training. Classrooms and projectors do not need to be reserved; materials do not need to be distributed. The sessions are easier to schedule or reschedule since attendees will not be travelling to the venue of the session.

In a Virtual Classroom environment, learners can talk to a teacher and to each other, and although this communication is not as rich as in a traditional classroom, it still can help learners, since it is one to one. Because of these advantages, the concept of the virtual classroom is getting very popular. Since it allows learners to attend sessions from anywhere in the world, it is very useful for distant learners and for people who cannot meet face to face because of lack of time. In spite of all the advantages, it has some faults also. Below, we are describing some of the limitations of the virtual classroom.

Being familiar with the procedure of the traditional classroom, teachers and students understand the concepts of hand raising, the blackboard, assignments, and so forth. With a virtual classroom, all the participants have to be familiar with the way the virtual classroom works before virtual classroom-based training starts.

Besides this, attending virtual classroom training is restricted to a certain scheduled time. Technical issues such as bandwidth speed of connection or power failure may cause a problem while the presentation is going on. Below is a Mind Map of Virtual Classrooms overview. They are available on the Internet. Some of them are free to use, but others are commercial ones.

If you want to create a virtual classroom you need to do the following:

1. Familiarize yourself with more Internet opportunities.

2. Revise international copyright laws.

3. Choose a good host for your website.

4. Find software which would enable you to interact with your students through chat sessions or forums.

5. Study carefully all information below.

If you want to create your own virtual classroom you will need the following tools:

1. Broadband Internet access.

2. Audio microphone, speaker and a webcam.

3. A shared screen ('the whiteboard') on which both the student and you can write (there is a software called Whiteboard Software).

4. Digital pen mouse for writing, drawing and highlighting text.

5. Your own website.

If you are serious about online tutoring, you need to have your own website to be able to promote your services as well as to communicate with your students. You will also need to get Whiteboard Software. Meanwhile, you can download an online course management system, a free software package Moodle which will give you a better idea of how to create an effective online 
learning community. You might also want to recommend your students to install Babylon software. In any case, you will still need to design your own website.

The effectiveness of educational technology on student learning depends not only on what outcomes are targeted and how the technology is integrated into instruction but also on how teachers assess student performance in classrooms and adjust instruction accordingly. Technology offers teachers a broad range of tools to collect and analyze data, and richer sets of student data to guide instructional decisions.

\section{References:}

1. Bax, S. (2011). Normalisation revisited: The effective use of technology in language education. IJCALLT, 1(2), 1-15.

2. Cavus, N., \& Ibrahim, D. (2009). M-Learning: An experiment in using SMS to support learning new English language words. British Journal of Educational Technology, 40(1), 78-91.

3. Cheung, C. K., \& Slavin, R. E. (2012). How features of educational technology applications affect student reading outcomes: A meta-analysis. Educational Research Review, 7(3), 198-215.

\section{Список литературы:}

1. Bax S. Normalisation revisited: The effective use of technology in language education // IJCALLT. 2011. V. 1. №2. P. 1-15.

2. Cavus N., Ibrahim D. M-Learning: An experiment in using SMS to support learning new English language words // British Journal of Educational Technology. 2009. V. 40. №1. P. 78-91.

3. Cheung C. K., Slavin R. E. How features of educational technology applications affect student reading outcomes: A meta-analysis // Educational Research Review. 2012. V. 7. №3. P. 198215.

Работа поступила

в редакиию 15.03.2019 2.
Принята к публикацуии 20.03.2019 2.

Cite as (APA):

Jalalova, I., \& Sagdullakhojaev, S. (2019). Virtual Classroom for Teaching English Language. Bulletin of Science and Practice, 5(4), 494-497. https://doi.org/10.33619/2414-2948/41/74.

Ссылка для изитирования:

Jalalova I., Sagdullakhojaev S. Virtual Classroom for Teaching English Language // Бюллетень науки и практики. 2019. Т. 5. №4. С. 494-497. https://doi.org/10.33619/2414$2948 / 41 / 74$ 